\title{
A Sapientia Erdélyi Magyar Tudományegyetem kutatási eredményei, különös tekintettel a múszaki tudományokra
}

DÁVID LÁSZLÓ

A Sapientia EMTE kapcsán bizonyára sokakban felmerült a gondolat, érdemes-e odairányítani a fiatalokat? Megfelelő képesítést nyújt-e nekik a szakmai érvényesülésükhöz? Hosszú távon életképes-e az Egyetem? Mindezek olyan kérdések, amelyekre meg sem próbálhatunk választ adni, ha nem ismerjük az egyetem által nyújtott képzések jellegét, kutatásait, fóbb célkitúzéseit, illetve az eddigi eredményeket. Cikkemben ezekre a kérdésekre szeretnék rávilágítani.

Amint azt az EMTE küldetésnyilatkozatában megfogalmazta: minőségre és nem csak tömegképzésre törő, versenyképes, a nemzetközi elvárásoknak megfelelő egyetem létesítése a cél. Ezért a képzési profil, illetve a kutatási témák meghatározásánál a hangsúly az információs társadalom és az EU-integráció által meghatározott követelményekre, témákra került. Fokozottan érvényes ez az állítás a csíkszeredai, valamint a marosvásárhelyi helyszínre, ahol az EMTE múszaki és informatikai képzési és kutatási rendszerének kialakítása történt meg. Bár Marosvásárhelyen a humán területek oktatása is jelentős hagyományokkal rendelkezik, hiszen tanárképző főiskola múködött ott, a múszaki területhez viszonyítva mégis hátrányosabb helyzetben van jelenleg, főként az elnyert kutatási támogatások tekintetében.

Az egyetem fejlesztési programjában a nagyon költségesnek számító múszaki fejlesztések támogatása csak nagy nehézségek árán vállalható. Ezek nélkül viszont nem várható el, hogy az EMTE magas színvonalú 
Gazdaságtudomány

Társadalomtudomány

Jogtudomány és múvészetek

Nemzeti-szervezeti kultúra és vezetési stílus az erdélyi magyar

kisebbségben

Régiófejlesztés, regionális kutatások

Filmtudomány

Helyszín: Csíkszereda-Marosvásár-

hely-Kolozsvár

\section{Biológia és milkrobio-}

lógia, élelmiszeripari mérnök, kertészet és agronómia

A PTP-BL- és a PRL-proteintirozin-foszfátok jellemzése

Élelmiszerek D-aminosav-tartalma

Peszticidek megmaradása és mozgása a

környezetben

Tejkoncentrálás ultraszűréssel, kompozitmembránok felhasználásával

A borkő kivonása és feldolgozása borászati

termékekből

környezetkímélő módszerekkel

A fenotiazinvázú hatóanyagok biodegradációjának tanulmányozása

Helyszín: Csíkszereda-Marosvásárhely
Környezetmérnök és környezettudomány

Zajtérképek, mofetták, nehézfémszennyezés Helyszín: Csíkszereda-Kolozsvár

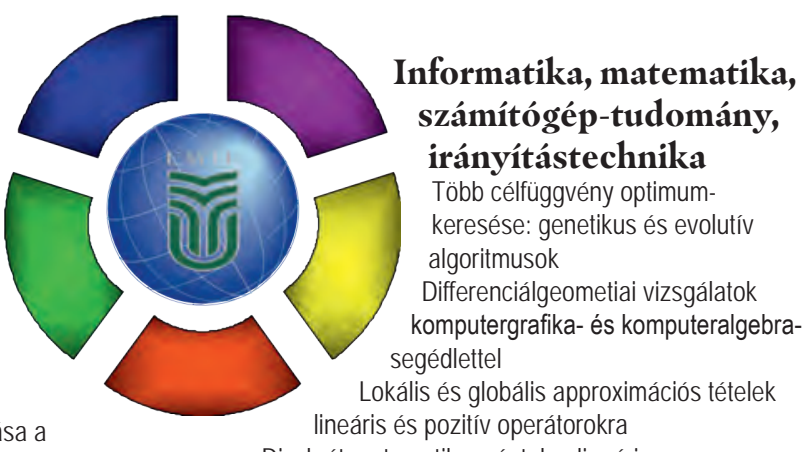

Diszkrét matematika, végtelen lineáris

egyenletrendszerek

Kaotikus rendszerek, dinamikus rendszerek vizsgálata perturbációs és fuzzy módszerekkel

Evolúciós döntési fák, valós idejü orvosi képalkotás, hardvereszközön megvalósított mesterséges neuronháló alkalmazása, hálózati forgalom modellezése Modellprediktív irányítások elmélete és gyakorlata Helyszín: Csíkszereda-Marosvásárhely

\section{I. ÁBRA: A Sapientia EMTE kutatási területei}

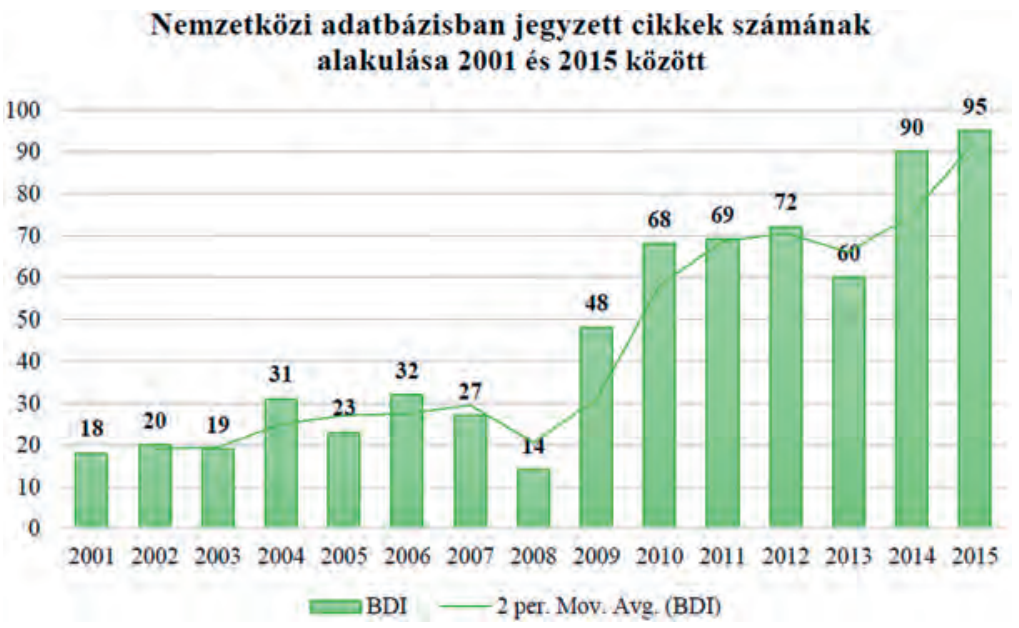

2. ÁBRA: A nemzetközi adatbázisokban jegyzett cikkek számának alakulása 2OOI-2OI5 között 
képzési, kutatási és szolgáltatási kínálatával, a képzés, a kutatás és a szolgáltatás egységes rendszerével, ezeknek a piaci igényekhez történő alakításával európai színvonalú felsőoktatási és kutatási intézménnyé tudjon válni. Természetesen ez nem lehet csak egy pár oktató feladata, hanem a tervezett szakirányok fejlesztésének a szakmai szempontból meghatározó jelentőségư intézmények és személyiségek közös koncepciója szerint kell történnie.

Az egyetem kialakuló tudományos arculatának már a kezdetektől tükröznie kellett a felvállalt képzéseket, ezért fontos volt, hogy a kutatások között egyenlő eséllyel kapjon szerepet minden szakirányt meghatározó témakör. Ezek csoportosítása a fenti ábrán követhető.

Ezek kapcsán feltehető a kérdés: milyen kutatásokat végez, és ennek kapcsán milyen kompetenciákat nyújt az Erdélyi Magyar Tudományegyetem? Vajon mennyire sikerült az eltelt I5 évben olyan tudományterületeket felkarolni, amelyek meghatározóak lesznek a következő periódusban?

$\mathrm{Az}$ összteljesítmény tekintetében egyetemi szinten a Sapientia EMTE oktatói által közölt, nemzetközi adatbázisokban jegyzett publikációk számának alakulása az alábbi ábrán követhető.

Jól látható a 2008-ra tehetó mélypont, amely egyfelől a kezdeti idószakra jellemző fóállású és társult oktatói arány átalakulásának, másfelől a periódusra jellemző egyetemi finanszírozási bizonytalanságnak a következménye. Ekkor azonban sikerült az addig alkalmazott keretfinanszírozást egy hosszú távú biztonságot jelentő, normatív finanszírozással helyettesíteni, amelynek hatása kedvezőnek bizonyult a tudományos alkotásokra is. A sikeres 20IO-es egyetemi intézményi akkreditáció két évet késleltetett 20I2-es törvénybe iktatása ugyancsak egy megtorpanást jelentett, de az azt követő periódusban alkalmazott egyetemi ösztönző rendszer kedvező hatása is jól követhető. Az intézményi kimutatások szerint 2015-ben összesen 478 publikációt jegyeztek az egyetem fóállású oktatói, ami átlagosan 2,39 publikációt jelent egy oktatóra, és ami majdnem megegyezik 20I4-es, egy oktatóra számolt átlaggal (2,42 - 20I4-ben 472 publikáció jelent meg). A következőkben pedig nézzük mindezt lebontva és részletezve.

ÉLELMISZERMÉRNÖKI KUTATÁSOK TÉMAKÖREI: Élelmiszerek összetételének meghatározása és új analitikai módszerek fejlesztése. Ennek keretében tejtermékek, sajtok zsírsavösszetételét, konjugált linolsav-, szabad aminosav-, illetve aminosav-tartalmát, a fehérje biológiai értékét, a Székelyföldön termesztett búzák, búzanövények és a búzából készült kenyér szelénés szelenoaminosav-tartalmát, a csíkszeredai és Csíkszereda környékén élő édesanyák tejösszetételét vizsgálják. 

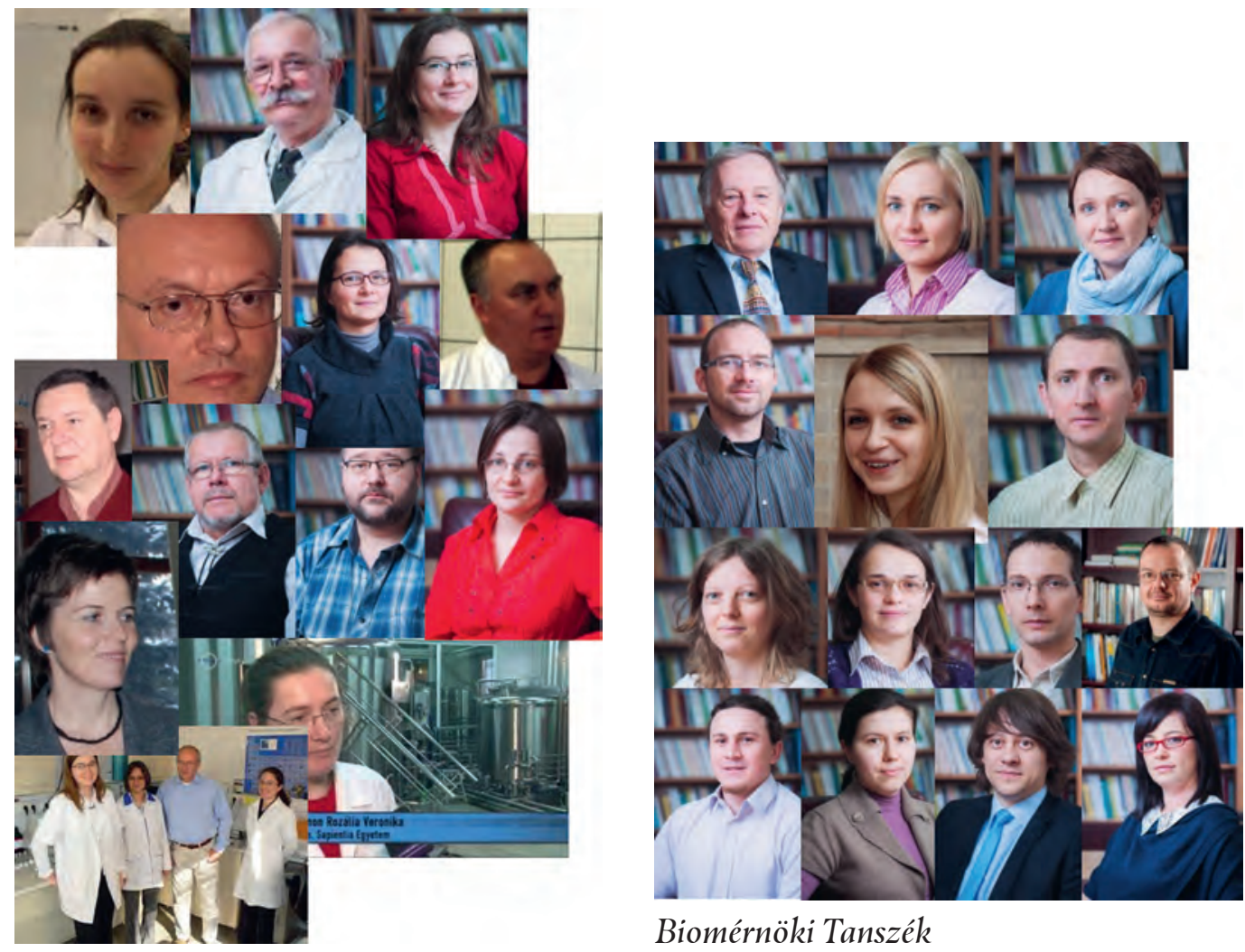

Élelmiszermérnöki Tanszék

Környezettudomány Tanszék

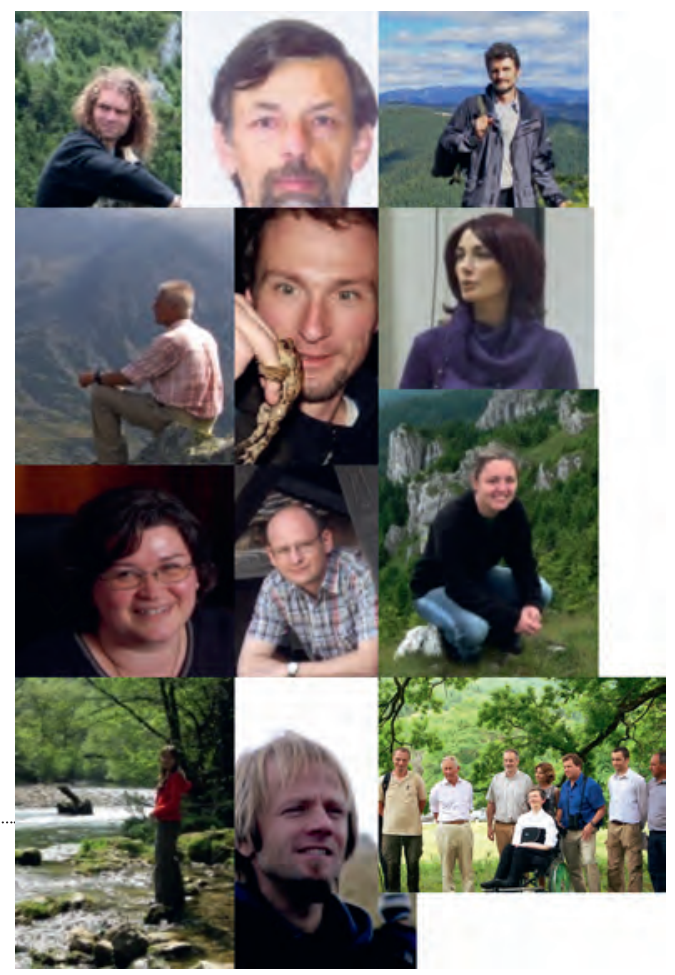


Példaként említhetô továbbá a szelénnel dúsított tej és tejtermékek elóállításának, valamint a gluténmentes liszt elóállítási technológiájának kidolgozása, amelyet lizin és transzglutamináz hozzáadásával valósítottak meg. Ugyancsak fontos témakört jelent a funkcionális élelmiszerek elöállitása, félszintetikus konjugált-linoleát adagolásával, valamint új fermentált termékek (pl. savós sör, mézzel ízesített sör) elóállítása, illetve a helyi aromanövények kivonatával és mézzel ízesített vermut elóállítása. A helyi hagyományos termékek értékesitése témakörben egy régi sörrecept laboratóriumi szintú technológiájának kidolgozása pedig a Magyar Terméknagydíjas „Igazi Csíki Sör” ipari szintú elóállításának alapját jelentette. A tanszéken élelmiszer-mikrobiológiai vizsgálatok is folynak, amelyek az allochton mikroorganizmusok tanulmányozására irányulnak, különféle élelmiszerminták esetén, illetve a természetes antimikrobás anyagok szerepének tanulmányozása a tartósításban.

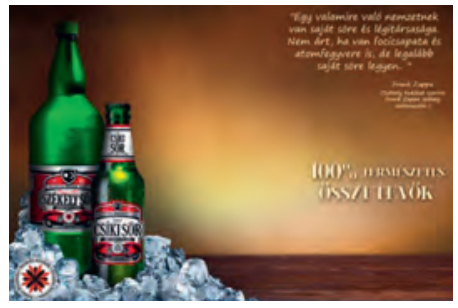

BIOMÉRNÖKI, VALAMINT KÖRNYEZETMÉRNÖKI KUTATÁSOK TÉMAKöREI: A biokémia, biotechnológia területén mutáns fluoreszcens proteinek expressziója és jellemzése, a diagnózisban és terápiában alkalmazható fehérjék expressziója, valamint olyan szélsőséges fizikai vagy kémiai tulajdonságú környezethez alkalmazkodott extremofil mikroorganizmusból izolált enzimek tanulmányozása, amelyeknek ipari felhasználásuk van.

Genomika és transzkriptomika területén a növényi stresszben szereppet játszó jelátviteli folyamatok, az emberi agyban mechanikai fulladás hatására expresszálódó Hsp-fehérjék, valamint apoptotikus jelzési útvonalak vizsgálatával foglakoznak.

Anyagcsere-mérnökség területén szukcinsav és butándiol elóállitását végzik olyan mikroorganizmusokkal, amelyek metabolikus útvonalait módosították.

Alkalmazott mikrobiológiai kutatások során olyan helyi ökoszisztémákból izolált talajbaktériumokat szelektált a csoport, amelyek különböző növényi növekedésserkentő mechanizmusok által használhatók a fenntartható mezőgazdaságban.

Környezeti mikrobiológia területén extrém élőhelyek (Medve-tó, Szent Anna-tó) mikrobiotájának a vizsgálata zajlik, míg a környezeti biotechnológiák témakörben biogáztermelés és szennyvíztisztítás modellezése történik.

A mikrobiológiai kutatások eredménye a fenntartható mezőgazdaságban és környezeti biotechnológiákban alkalmazható törzsek gyújiteménye. 
Az extrém élőhelyek mikrobiotájából pedig a tudomány számára 4 új baktériumfaj került elö, amelyből két új nemzetséget írtak le az egyetemünk munkatársai.

A KöRNYEZETTUdOMÁNYI KUTATÁsOK egyik fó irányvonalát az erdélyi települések zajtérképének az elkészítése jelentette. Párhuzamosan folyt a természetes építőanyagok radioaktivitásának és radonszennyezettségének a tanulmányozása, valamint a kolozsvári ipari terek gondjainak, illetve a Kolozsvár környéki tanösvények lehetőségeinek a feltérképezése. A szőlőfeldolgozásból, illetve a háztartásokból származó anyagok újrahasznosítása, valamint a beltéri vizes élőhelyek és a Kis-Szamos vízminősítése egészíti ki az eddigi kutatásokat. Nagyon jelentős Hartel Tibor kutatása az erdélyi fás legelők szociális és ökológiai vonatkozásairól, amelyet Károly herceg is felkarolt, nevezetesen a Miklósvár melletti tölgyfás legelő tanulmányozását.

Az ÜZLETI TUDOMÁNYOK TANSZÉK kutatási témakörei elég szerteágazóak. A diszkrét választású modellekre épülő keresletmodellek becslése és az ezekhez kapcsolódó célfüggvények tanulmányozása, valamint ezek alkalmazása az egyensúlyban lévő mikroökonómiai rendszerekre jelenti az egyik fó kutatási területet, de ugyancsak fontos a szemiparametrikus maximum likelihood (maximális valószínúségú) becslők aszimptotikus tulajdonságainak a vizsgálata, valamint a kvázirandom felmérések ökonometriai alkalmazásai, különös tekintettel a kapcsolt választású kísérleti adatokra. Mindezek mellett különböző vidéki és regionális politikák, valamint fejlesztések kidolgozásával is foglalkoznak, amely természetesen része a regionális tudományoknak, és olyan kérdéseket vizsgáltak, mint a regionális versenyképesség, a települések földrajza, településhálózatok vagy a városok szerepe a térség gazdaságában. Továbbá a térségek marketingje, a turizmus, térségek fejlödése és gazdasága, vidékfejlesztés, valamint a térségi foglallkoztatás és munkanélküliség vonja magára a tanszék kutatásainak érdeklődését.

A gAZDASÁgTudománYi TANSZÉKCSOPORT a vidékfejlesztés, agrárfarmok, a regionális fejlesztés, a területfejlesztés, a munkavállalási migráció hatásai Hargita megye gazdaságára a 2012. október I. és 2013. március 3. közötti időszakban, valamint a regionális versenyképesség és a szervezeti kultúra hatásai mellett számos alkalmazott matematikai kutatással is foglalkozik mint optimumkeresés genetikus, illetve fuzzy módszerrel, az információ diffúziójának bizonyítása háromszög-fuzzy-tagsági függvények esetében. Csillagászati modellezés, saját Wisdom-Holman-integrátort dolgoz- 


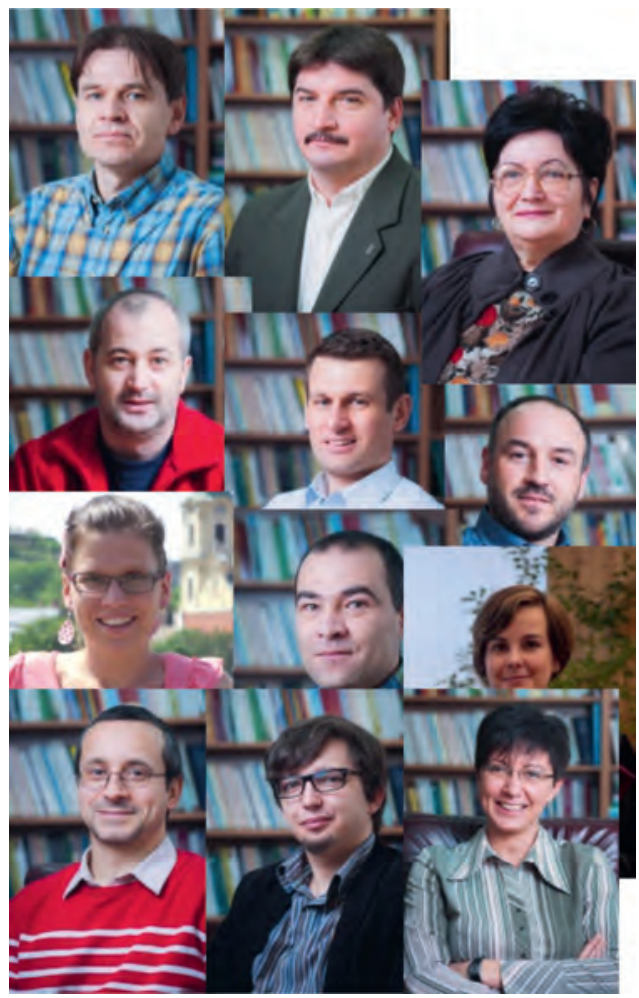

Üzleti Tudományok Tanszék

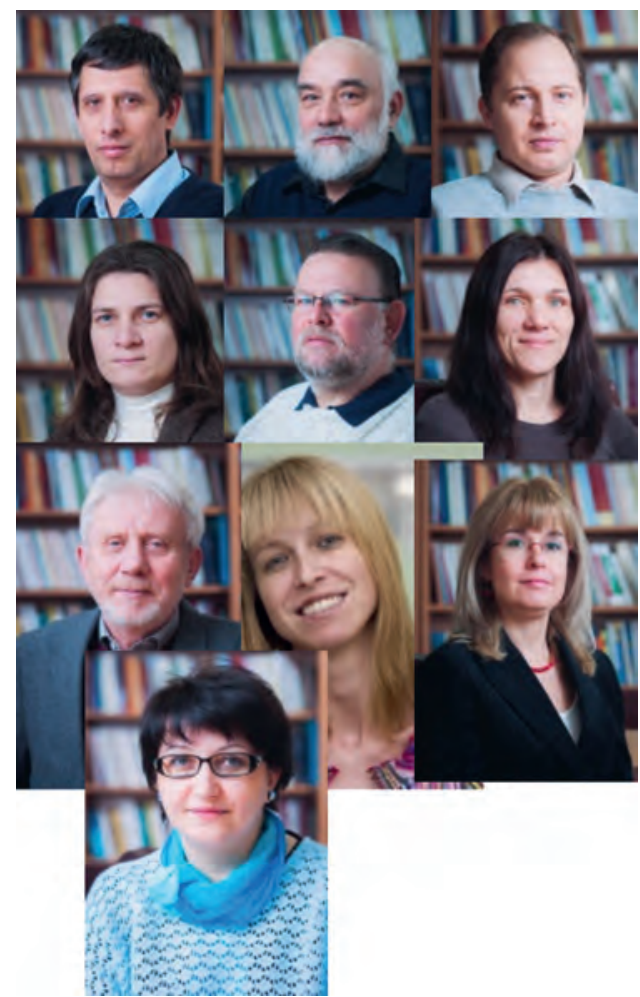

Gazdaságtudományi Tanszék

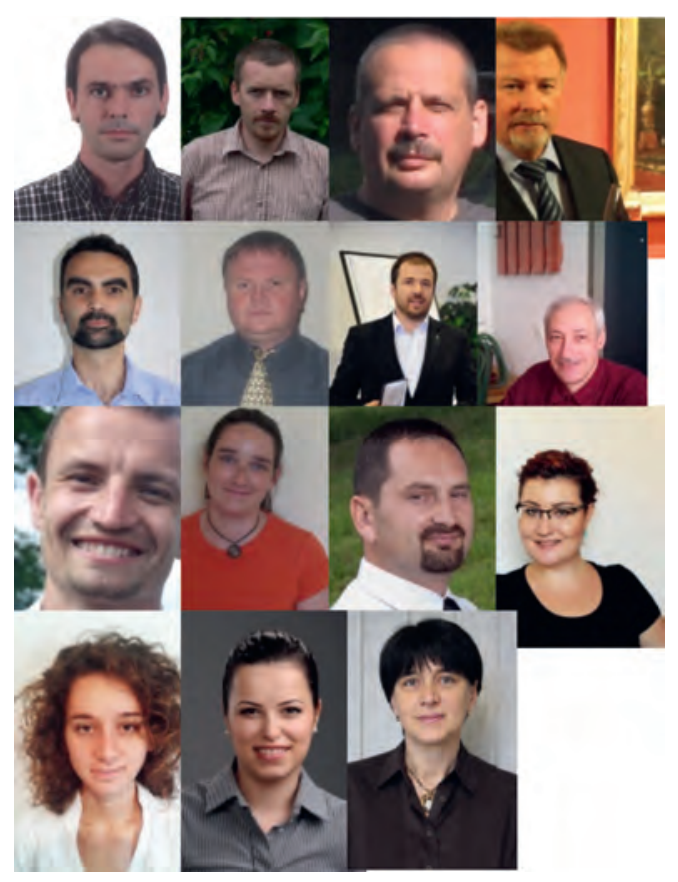

Kertészmérnöki Tanszék

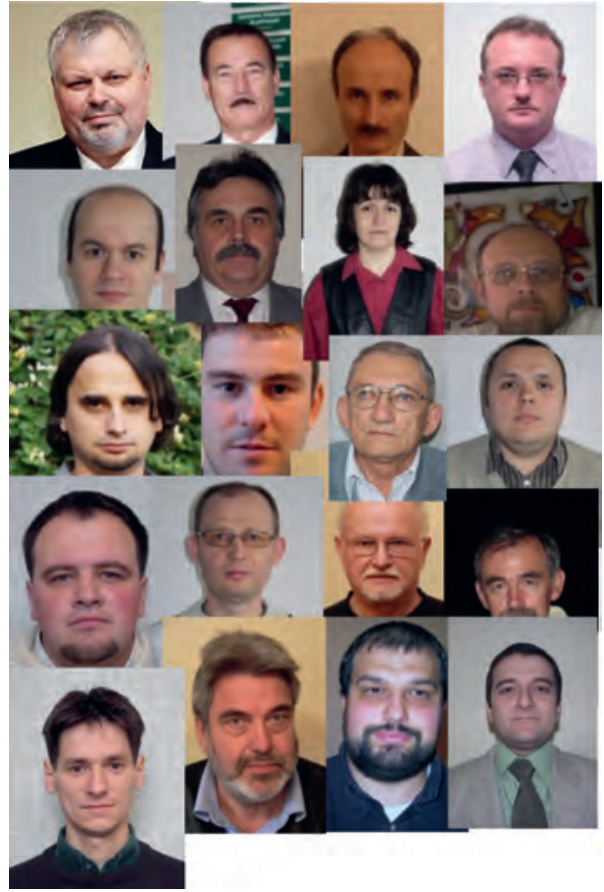

Villamosmérnöki Tanszék 


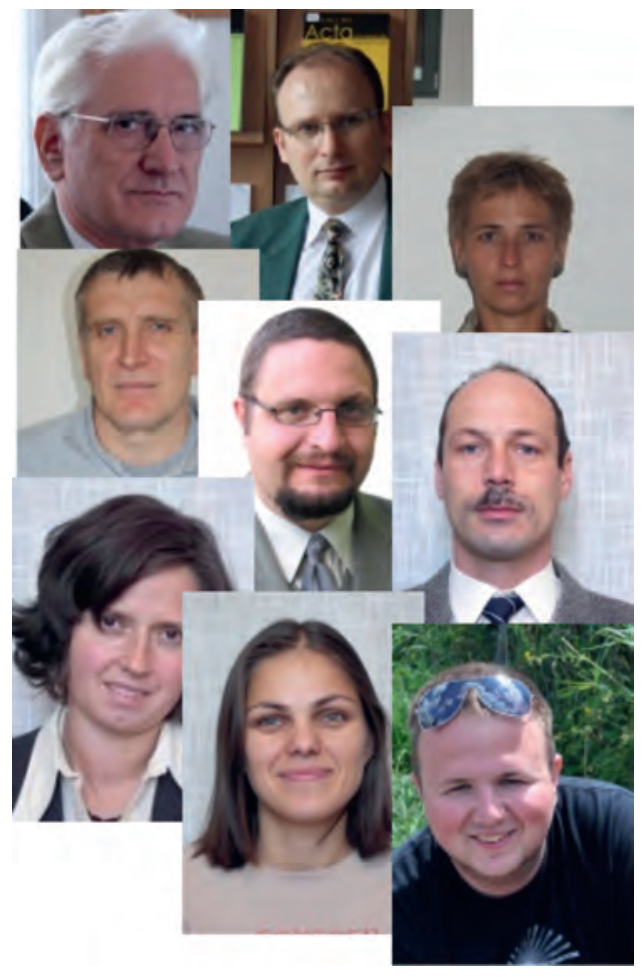

Matematika-Informatika Tanszék

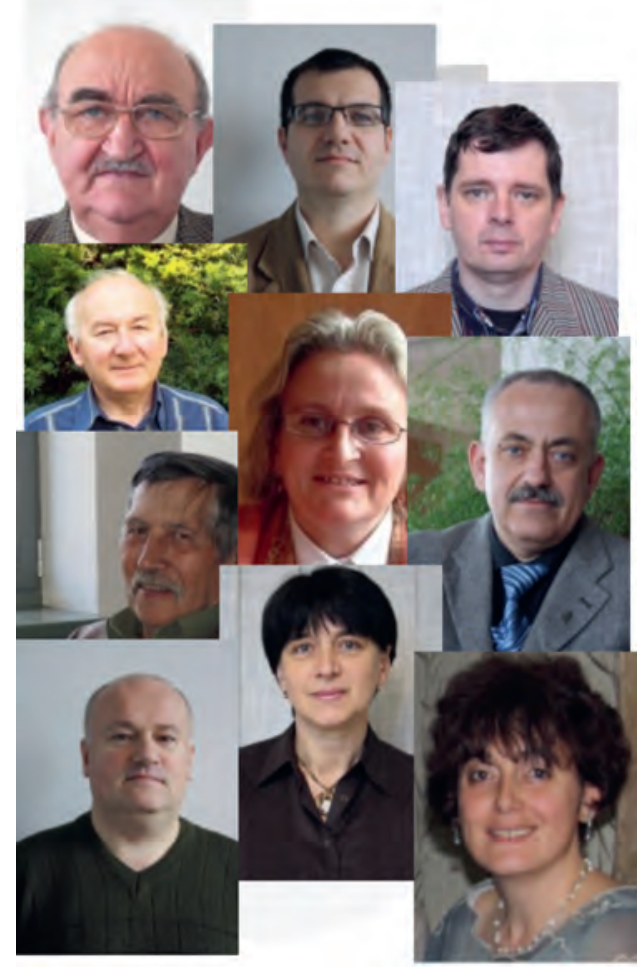

Gépészmérnöki Tanszék

tak ki az N-test feladathoz, és mesterséges neuronhálókat is alkalmaztak a csillagászati feladatoknál. Jelentős matematikatörténeti eredményeik közül fontos a Bolyai-kutatás.

A szabási feladatok numerikus módszereivel, valamint a Barry-Levinsohn-Pakes-piaciegyensúly modellezésével is értek el újszerú eredményeket.

Bebizonyították a paraméteres vektoregyensúlyi feladatok paramétertől függő megoldásfüggvényének gyenge zártságát és az általános Hadamard jól értelmezettségét, amelynek érdekében úi vektortopologikus pszeudomonotonitási fogalmakat vezetettek be.

Ezenkívül a globális optimumkeresés, a különböző szenzorok lokalizálása globális optimumkereséssel is érdeklődésük része.

KERTÉSZMÉRNÖKI, TÁJÉPÍTÉSZ ÉS AGRÁrMÉRNÖKI KUTATÁSOK: Romániában csak a Sapientia EMTE keretében múködnek magyar nyelvú agrártudományi szakok. Az itt folyó oktatás és kutatás célja olyan agrárértelmiségi szakemberek képzése, akik a tudomány és a gyakorlat legújabb ered- 
ményeit magas szinten ismerik, és azokat hasznosítani tudják a kertészet legalább egy alapvető ágazatában. azaz a gyümölcs-, zöldség-, dísznövény-, gyógynövény-, szőlootermesztés és növényvédelem területén. Jelentős a gyógynövények, valamint a kertészeti növények ellenállóságát befolyásoló környezeti, biológiai és genetikai tényezők vizsgálata. Ezt kiegészíti a kemotípus-varianciák és azok jelentősége vadon élő növényeken és kertészeti kultúrákban kutatása, valamint a biológiai növényvédelem szimbiontákkal és természetes ellenségekkel. Az alkalmazott kutatások osztályába tartozik a kertészeti növények mennyiségileg és minőségileg magas, gazdaságilag hatékony terméshozamát biztosító technológiai tényezők kutatása és az erdélyi őshonos kertészeti növények sokféleségének megơrzése és bővitése értékes biotípusok morfológiai, élettani, biokémiai és gazdasági értékeinek azonosításával, felmérésével és szaporítástechnológiájuk kidolgozásával. Ezeket egészíti ki a kertészeti termelés szennyező tényezőinek azonosítása és ezek megelőzési lehetőségeinek kutatása. A tájépítészet keretében folyik az erdélyi történelmi táj természeti, kulturális és társadalmi értékeinek felmérése és revitalizációs programjának elkészítése.

Gépészmérnöki kUtatások témakörei: Profilhibamentes és pozitív homlokszögú csigamaró elméleti modelljének megalkotása. A csigamarónak, bár a legelterjedtebb és mindmáig az evolvens hengeres fogaskerék-lefejtő szerszámok közül a legtermelékenyebb, elméleti profilhibája van, és ennek csökkentése érdekében nem megfelelő geometriát is elfogadnak a konstruktőrök. A klasszikus csigamaró hátraesztergált, illetve hátraköszörült oldalhátfelületei profiltartók ugyan, de az újraélezések során az él közelebb kerül a szerszámtengelyhez, és emiatt felülettorzulás keletkezik.

A kutatási témának célja a jelenleg létező szerszám geometriai és konstruktív paramétereinek módosítása volt. A módosítás a jobb forgácsképzést, illetve pontosabb legyártott fogaskerékprofilt segíti elő. Az elért eredmények közül megemlítjük azt, hogy megvalósítottak egy pozitív homlokszögú csigamarót, melynek profilja a DIN-szabványtól eltér a homlokszög okozta módosításokkal. A homlokfelület geometriai szempontból nem tér el a klasszikus csigamaró homlokfelületétől, így technológiai nehézségek sem merülnek fel.

A spirálfogazatú hengeres kerekek geometriája és gyártástechnológiája téma keretében az evolvens hengeres külső kerekek kapcsolódása - egyenes vagy dőlt fogazat esetében is - két domború felületen történik. A Hertz-féle kontaktuselmélet alapján kijelenthető, hogy a domború-homorú felületpáron történő kapcsolódással nagyobb terhelhetőséget biztosítha- 
tunk. A téma célja sajátos lefejtési elv alapján létrehozott homorú-domború kapcsolódású hengeres fogaskerékpár szintézise volt. A származtató felület egy Arkhimédész-féle spirális vezérgörbére alapozó vonalfelület. A származtató felület pedig egy, a relatív elmozdulás következtében görbületét változtató fogaslécet hoz létre, amely kapcsolódik a hajtópár két fogaskerekével, amelyek egymással is kapcsolódnak. A javasolt lefejtés a származtató felület saját tengelye körüli forgásával, radiális előtolás útján valósul meg úgy, hogy a lefejtett fogaskerék tengelye és a származtató felület tengelye kitérően merőlegesek, köztük a tengelytáv nem változik.

Az elért tudományos eredmények közül fontos a hajtópár szintézise, a görbületét változtató generáló fogasléc elméletének kifejlesztése, igazolása, valamint a generálás szimulációja és a hordkép kielemzése.

Újszerú kutatást jelent a súrített levegóvel múk ödtetett bolygódugatytyús motor is. A kutatás keretében egy forgódugattyús (pontosabban: bolygódugattyús) pneumatikus motort fejlesztenek. E motor felépítésében a Wankel-motorra emlékeztet, amely egy belső égésú motor. Az újítás abban áll, hogy a motor sürített levegóvel fog múködni, és nem egy, hanem két vagy több egyidejúleg aktív munkatere van.

Ezek mellett jelentősek a robotirányítások területén elért eredmények, valamint a tudománytörténeti kutatások, amelyek számos publikációt eredményeztek.

A villamosmérnöki tanszékkel közös kutatási téma a nanotechnológiák közé sorolt vékonyréteg-technológiák, nevezetesen a reaktív mágneses porlasztással növesztett vékonyréteg-technológia. Ennek keretében teremtett kutatási infrastruktúrát a dr. Bíró Domokos által vezetett kutatócsoport. Alapkutatást, valamint alkalmazott kutatásokat végeznek az átmeneti fémek ( Ti, Zr, Al, Cr, Si, N, C, MoS2,) nitrát és karbonitrát nanokompozit anyagok tulajdonságai, multiréteg-struktúrák tribológiai tulajdonságainak tanulmányozása területén.

A vákuumfizika és alacsonynyomású gázokban gerjesztett plazmakisülési folyamatok tanulmányozása után jelentős elméleti és gyakorlati kutatási tevékenységet jelent a plazmakisülésben porlasztásos eljárással leválasztott vékonyrétegek elóállítása, szerkezeti és összetételi vizsgálata terén. Saját tervezésú magnetronos porlasztási kísérleti berendezést fejlesztettek. Ezek az eredmények szervesen kapcsolódnak a Magyar Tudományos Akadémia Múszaki Fizikai és Anyagtudományi Kutató Intézet Vékonyréteg Fizikai Osztály tevékenységéhez. Közel egy évtizedes együttmúködés keretében részt vett és meghatározó szerepe volt az Európai COST5I6 (I9972000), COST532 (2002-2007), (I997-2000), EU FP5 NANOCOMP 
(200I-2004), valamint a "NATO Fellowships Programme Science for Peace” (2003-2004) nemzetközi együttmúködési programokban.

Jelenlegi kutatási tevékenységük tárgya a fémkerámia-típusú vékonyréteg anyagok elóállítására és vizsgálatára vonatkozik, amelynek keretében amorf és nanokristályos TiAlN-, ZrCuN-, Ti-C/N-, TiAlSiN-, TiAl-MoS2multirétegek gradiens összetételú előallítását és mikroszerkezeti vizsgálatát végzi. A kísérleti rendszer automata folyamatszabályozása terén kifejlesztették a szakirodalomban először alkalmazott fuzzy-vezérléses reaktív magnetronos porlasztási módszert.

Eredményeiket Magyarországon is értékelték. Így Arany János Kiemelkedő Tudományos Teljesítmény Díjat, valamint In Memoriam Gábor

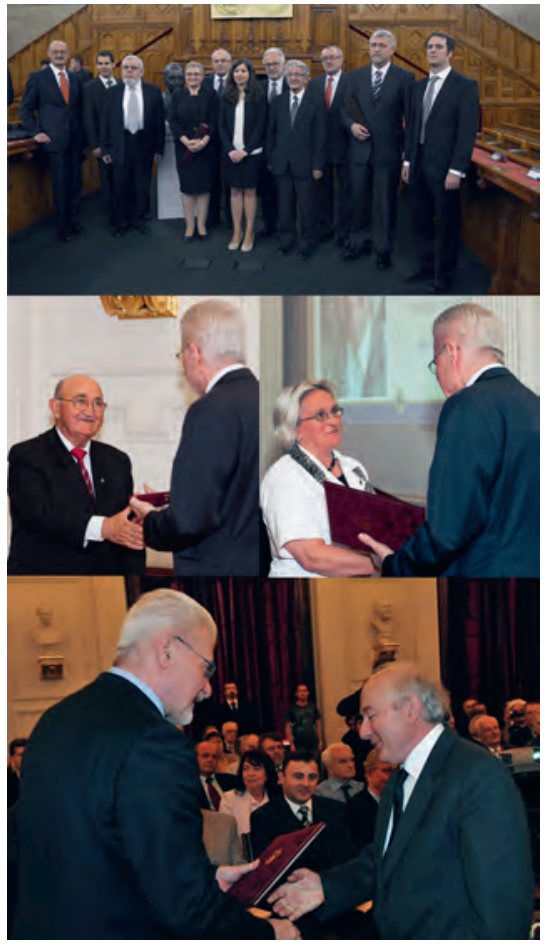
Dénes-emlékérmet kapott Bitay Enikő, a Sapientia EMTE docense, az EME fótitkára, akinek sokoldalú tevékenysége számos területet fog át: az anyagtudományi kutatások, a múszaki és informatikai felsőoktatás, a múszaki utánpótlás-nevelés és az erdélyi korszerú kutatásszervezés egyaránt sokat köszönhet munkásságának. „Arany János-éremmel ismerte el a Magyar Tudományosság Külföldön Elnöki Bizottság Hollanda Dénes tevékenységét. A Sapientia Erdélyi Magyar Tudományegyetem (EMTE) nyugalmazott emeritus professzora, volt dékánja nélkül aligha lenne ma magyar nyelvú múszaki oktatás Erdélyben. Küldetéstudata eredményeképpen az erdélyi magyar múszaki értelmiség generációi indulhattak el pályájukon.” És így kapta meg Bíró Domokos, a Sapientia docense is kimagasló kutatási eredményeiért az MTA Arany János-diját 2ori-ben.

A vilLAMOSMÉRNÖKI TANSZÉKNEK a vékonyréteg-, valamint a plazmanitridáló berendezések és technológiák mellett jelentősek az orvosi, valamint a biológia területén végzett jelbegyújtésben és -feldolgozásban elért eredményei is. A biológiai jelmérés és jelfeldolgozás területén (biológiai jelek, beszédtechnológia, képfeldolgozás) újszerú hardverelemeket és algoritmusokat fejlesztettek az EKG-, az EEG-jelfeldogozásra, különös tekintettel a kombinált frekvencia- és időtartományban való feldolgozásra. Az elért 
eredmények és kidolgozott szoftverek a Hilbert-Huang-transzformáció alkalmazásán alapulnak, amelyeket a oxfordi Neuroscience kutatólaboratóriumban is használnak. A jeleket méró és begyúijtő rendszer aranyérmes találmány dijat nyert a ProInvent találmányi versenyen. Jelentősek a kalciumfelszabadulási jelenségek számítógépes elemzése érdekében fejlesztett szoftvereredmények is. A tanszék részt vállalt a beszédfelismeró és beszélőfelismerő szoftverfejlesztésben, valamint a beágyazott rendszerek és mesterséges intelligencia módszereinek a jelfeldolgozásban való alkalmazásában, amelynek létezik hardveres megvalósítása is. Jelentősek a teljesítményelektronika, villamos hajtások és a mechatronika területén elért eredmények, valamint a számítógépes információfeldolgozás, számítógépes hálózatok és távközlési rendszerek segítségével végzett kutatások. Ilyen a hálózatokon megvalósított irányítások, intelligens és autonóm irányítások rendszere, valamint az alkalmazott robotirányítások. Orvosdiagnosztikai szoftverek fejlesztése saját fejlesztésú klaszterező algoritmusokkal, többek között robusztus fuzzy, valamint c-means algoritmussal és a kézfertőtlenítést ellenőrző rendszer, amelyet a nemzetközi US 201302I5245 Ai Patent véd. Jelentősek a modellalapú prediktív irányítások (MPC) területén elért eredményeik is. A módszerrel korlátos optimális irányítás valósítható meg, amennyiben a számítási idő biztosítja a gyakorlati alkalmazhatóságot. Ezért a saját fejlesztésú explicit MPC-irányítás szoftvere számos gyakorlati irányítási feladat esetében használható, továbbá tanulmányozták az állapotteres MPC-, illetve a nemlineáris rendszerek állapotfüggő Riccati-egyenleten alapuló irányítási algoritmusát.

A Matematika-INformatika Tanszéken három kutatócsoport múködik: Matematika, Hálózatok és alkalmazások, Számítógéppel támogatott oktatás. A fóbb kutatási területek, amelyekben jelentős eredmények születtek az elmúlt 5 évben:

\section{MATEMATIKAI TUdomáNYOK (ISI: I9, BDI: 6):}

A diszkrét matematika területén a gráfelméleti algoritmusok alkalmazását kutatják, amelyet döntési folyamatok optimalizálására használnak, célzatosan szociális hálókban vagy a „dolgok internete” területén, de ugyancsak használható a gyors MPC-szoftverek megvalósításánál is. Hasonló témakört jelenthet a variációszámítás, geometriai analízis (függvényegyenlőtlenségek tanulmányozása görbült tereken stb.) kritikuspont-elmélet vizsgálata az algebra és analízis eszközeivel, mert az optimális irányítás megoldásának az alapját is jelenti a variációszámítás. A Gamma-függvényre vonatkozó egyenlőtlenségek és alkalmazásaik, valamint a komplex függvények tanul- 
mányozása (analitikus függvények csillagszerúsége és konvexitása) ugyancsak újszerú gyakorlati algoritmusokhoz vezet.

\section{INFORMATIKAI TUDOMÁNYOK (ISI: 2, BDI: IO):}

$\mathrm{Az}$ informatika alkalmazások esetében a kriptográfiai rendszerek fejlesztése; hálózati modellek és hálózatok biztonsága, adatbányászat/adattudományok, a „Formal Concept Analysis”-alkalmazások, érzelemelemzés, IoT-alkalmazások kutatása, valamint viselkedésalapú biometria és a biometrikus minták minőségi elemzése jelenti a főbb témaköröket. Mindezek célja az intelligens és folytonos hitelesítés megvalósítása. Végül a dinamikus programozás tanulmányozása d-gráf modellekkel kutatást említem.

OKTATÁsTUdomÁNYOK (ISI/„A-kategória”: 9, BDI: 4)

Ezek olyan informatikai alkalmazások, amelyek az oktatástudományokban alkalmazhatók, azaz interdiszciplináris informatikai alkalmazások. Céljuk a programozás-oktatás hatékonyságának növelése, valamint a számítógéppel támogatott oktatás.

Mindezek alapján a jelentős tudományos munkásságú külhoni magyar tudósok, kutatók jutalmazására szolgáló Arany János-életmúdíjat a Magyar Tudományos Akadémia 2013-ban Weszely Tibornak, a matematikai tudomány doktorának, a Sapientia Erdélyi Tudományegyetem nyugalmazott egyetemi docensének ítélte oda, a magyar matematikatörténet kutatásában, különösképpen a Bolyai-kutatásban elért forrásértékú eredményeiért, geometriai kutatásaiért, valamint több mint fél évszázados, kiemelkedően eredményes oktatói tevékenységéért. Ugyancsak nemzetközi díjban részesült Kátai Zoltán tanárunk, aki 20I3-ban megkapta a „Best Practices in Education Award

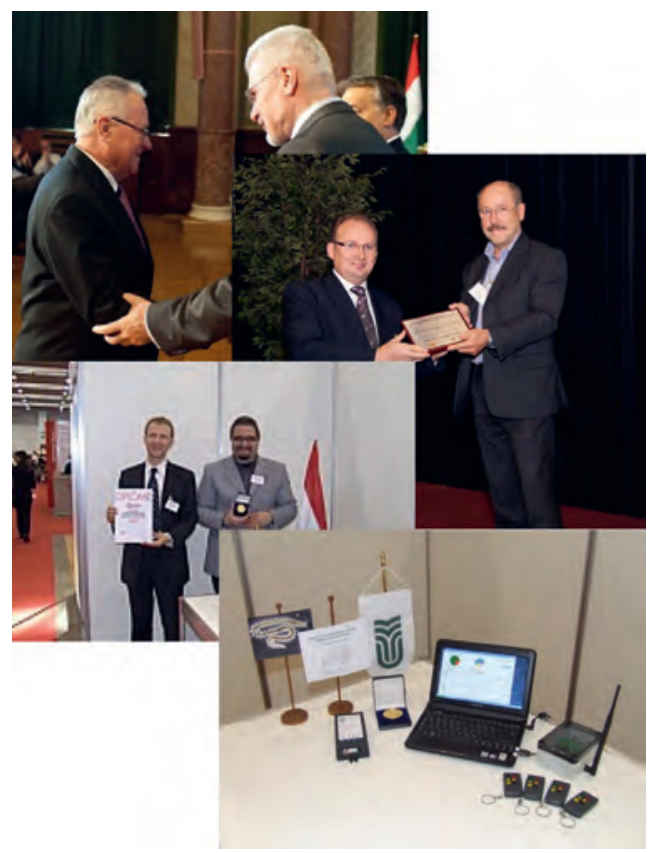
(Informatics Europe)" díjat, az informatikaoktatásban bevezetett újszerú módszerért. Informatikus és villamosmérnök kollégáink pedig aranyérmet nyertek a 38. Genfi Nemzetközi Találmányi Szalonban az oktatás hatékonyságának növelésére szolgáló berendezéssel 20Io-ben. 


\section{Összegzés}

A Sapientia EMTE keretében nagy egyetemekre jellemző, szerteágazó kutatási témákat láthatunk. Talán többet is, mint az optimális lenne. Ennek oka az alulról jövő kezdeményezés, amely egy új intézmény esetében jelentős és hatékony eredményorientált környezetet tud teremteni. Hosszú távon viszont szükségessé válik a témák szúkítése, amelyeket alá kell rendelni az erős tudományos csoportok múk ödésének, céljainak. Bár már most is érzékelhetó, hogy tanáraink eredményeit értékelik mind itthon, mind külföldön, de mindez csak úgy jelentheti egy intézmény megerősödését, amennyiben a kutatási témák koherens módon néhány nagyobb célt megfogalmazó csoportba tömörülnek. Érvényes az a megállapítás is, hogy múszaki kutatóink és oktatóink igen korszerú témákkal foglalkoznak, és szép számban nyertek el hazai, valamint európai projekteket. Az idősebb kutatók mellé pedig felzárkóztak a fiatalok, biztosítva az utánpótlást ezen a téren. Az utóbbi évek viszont épp az idősebb generáció kifutását hozták, így a fiataloknak maguknak kell folytatni az elkezdett kutatásokat, illetve megfelelő partnert találni ezek finanszírozására.

$\mathrm{Az}$ ehhez szükséges személyes kapcsolatok kialakultak és léteznek, intézményesítésük viszont még folyamatban van.

\section{KÖNYVÉSZET}

- Sapientia Erdélyi Magyar Tudományegyetem. Az első tíz év. Kolozsvár, Scientia Kiadó, 2010.

- http://www.informatics-europe.org/services/curriculum-award.html

- http://www.acta.sapientia.ro/

- http://www.sapientia.ro/hu 